\title{
JPEB
}

\section{THE LEVEL OF SERVICE QUALITY OF FAST-FOOD RESTAURANTS IN SEMARANG}

\author{
Imam Nuryanto $^{1 *}$ dan Ida Farida ${ }^{2}$ \\ ${ }^{1,2}$ Management Study Program, Dian Nuswantoro University Semarang \\ Nakula Street I Number 5-11 Semarang, Indonesia \\ *Corresponding Author: imam.udinus@gmail.com
}

Received: February 2020; Revised: July 2020; Published: September 2020

\begin{abstract}
The purpose of this research is to find out the influence of service quality (tangible, reliability, responsiveness, empathy) on customer loyalty. The object chosen in this research is fast-food restaurant in Semarang. The sample in this research is determined by purposive sampling method which then obtained the number of a sample as many as 100 respondents. The data in this research were obtained by the questionnaire. The data analysis used in this research is multiple linear regression analysis methods. The results of this research prove and give the conclusion that: service quality has a positive and significant influence on customer loyalty. The empathy variable is the highest variable affecting customer loyalty, because during the COVID 19, personal service was needed. Each consumer is unique, so the needs of customer services vary. Customers can use delivery or take away, home delivery, drive-thru, online and KFC box services
\end{abstract}

Keywords: service quality; customer loyalty; fast-food restaurant 


\section{INTRODUCTION}

During the outbreak of the corona outbreak in 2020, now it requires the public to pay attention to the government's affirmation to prevent wider spread. With these conditions, culinary business people, especially fast-food restaurants, cannot close and must continue to operate. Restaurants can remain open, but it is necessary to pay attention to many things including improving services and providing facilities according to the standards for preventing the corona / COVID virus pandemic 19 (https://ekonomi.bisnis.com). To serve customers who want to keep coming to the restaurant, the business owner must provide extra facilities. Namely, washing hands sink, following the government SOP on the prevention of the corona virus. Among them are providing hand sanitizers for guests at the entrance and most importantly maintaining the cleanliness and health of staff or employees. Today's competition between fast-food restaurants is no longer oriented towards increasing sales volume but more oriented on how to create loyalty. Marketing has an important role in the company to create value for customers and build strong relationships with customers. The higher the level of competition, will cause customers to face more alternative choices for products, so that customers will always look for the value that is considered the highest of several products (Kotler 2005). Low service quality will lead to decreased customer loyalty, therefore efforts to improve service quality will be much more effective for business continuity. One of the businesses most concerned with the level of service today is fast-food restaurants. Competition for fast-food restaurants cannot be avoided, because various similar restaurants have sprung up in the city of Semarang. Semarang is one of the cities in the province of Central Java and is the provincial capital. The development and population density make Semarang the 5th largest metropolis in Indonesia. The fast-food restaurant business in 2019 is believed to grow 15\%, supported by the sentiment of improving public incomes and the increasing trend of dining outside the home. The performance of the fast-food restaurant business is supported by improvements in public consumption as reflected in the consumer confidence index (CCI) which always increases every year. Based on a Bank Indonesia survey, the CCI reached 110 points in 2016 and continued to rise to the level of 123.5 at the beginning of 2019 (https://jateng.idntimes.com).

KFC fast-food restaurant is an American fast-food restaurant chain headquartered in Louisville, Kentucky, that specializes in fried chicken. It is the second-largest restaurant chain in the world (measured by sales) after McDonald's, with 22,621 locations globally in 150 countries as of December 2019. In Semarang, there are 5 KFC stores namely KFC Candi, KFC Pandanaran, KFC Citraland Mall, KFC Java Supermall, and KFC Youth. The application of social distancing or social distancing to anticipate the spread of the corona virus (COVID 19) has an impact on the culinary industry sector. After the enactment of the appeal, fast-food restaurant entrepreneurs complained about the decline in guest visits or food orders. Helping the government in running the social distancing program, KFC urges its loyal customers to use delivery services, both take away, home delivery, drive-thru, online, and KFC box. Even though it has decreased, but KFC fast-food restaurants are still at the top of the Top Brand until 2019 phase 2 (https://www.topbrand-award.com). Based on the background and competition 
faced by KFC fast-food restaurants, it is interesting to research on The level of Service Quality of fast-food restaurants in Semarang.

\section{LITERATURE REVIEW}

\section{Service Marketing}

The definition of marketing (marketing) according to Kotler (2012:220) is a human activity that is directed to fulfill needs and wants through an exchange process. Meanwhile, services according to Lovelock (2010:15) is a form of leasing that can provide benefits for consumers. So it can be concluded that service marketing is a process that creates and delivers services that consumers need. Where in it there are activities such as attracting consumer attention, retaining consumers which are all done to meet the needs and desires of a company that runs a business.

\section{Service Quality}

Service Quality according to Tjiptono and Chandra (2012:74) Service quality reflects the comparison between the level of service delivered by the company and customer expectations. According to Kotler (2012:285), There are five dimensions or determinants of service quality, the five dimensions include: First tangible are tangible aspects that can be seen and felt. Second, reliability is the reliability aspects of the service system provided by the service provider. Third, responsiveness is the desire to help consumers and provide the services needed. Fourth, assurance is a service guarantee that assures security, ability (competence) of resources in providing services. Fifth, empathy (empathy) is related to ease of service, friendliness, communication, and the ability to understand consumer needs.

\section{Customer Loyalty}

The definition of customer loyalty according to Tjiptono and Chandra (2013:88) stated that so far, customer loyalty has often been linked to repurchasing behavior.

\section{RESEARCH METHODS}

The population in this study were consumers who had consumed or visited KFC fastfood restaurants in Semarang with a total of 100 respondents. Sampling using purposive sampling technique with criteria, among others: aged over 17 years, domiciled in Semarang, have consumed KFC fast-food restaurant products.

\section{RESULT AND DISCUSSION}

\section{Respondent Description}

Respondents in this study were taken from consumers who had been to KFC fast-food restaurants, aged over 17 years and domiciled in Semarang. The questionnaire was distributed to 100 respondents. The validity and reliability test results for all indicators are valid and reliable. And the classical assumption test has been done, so it is feasible to do a regression analysis model in this study. The analysis used in this study uses multiple linear analysis, with the following conceptual framework: 


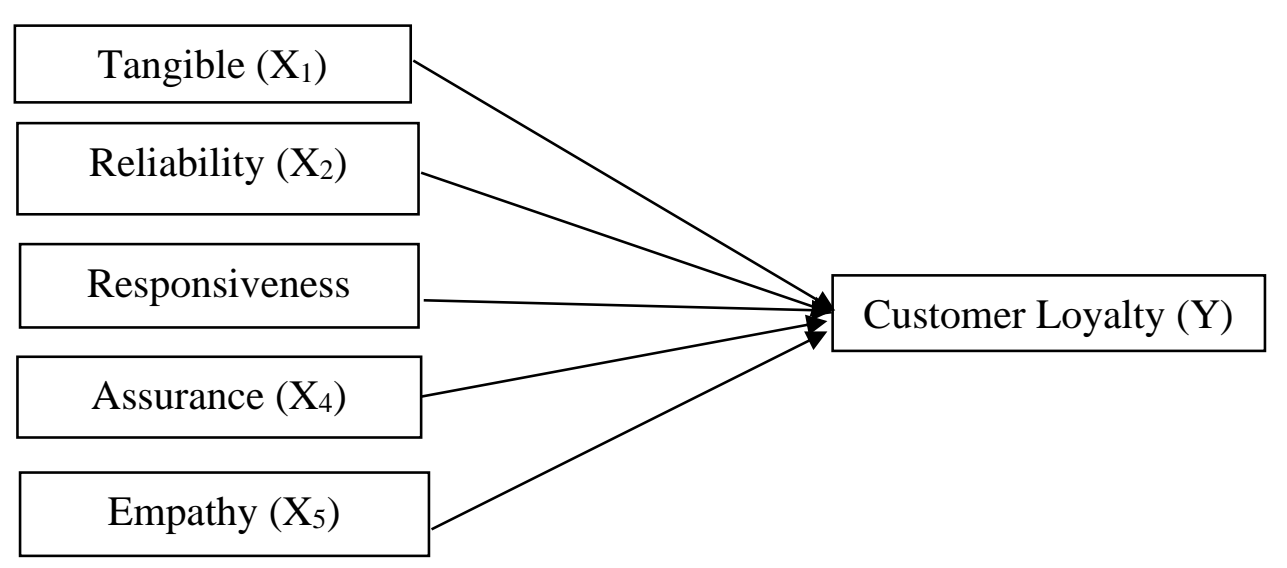

Figure 1. Conceptual Framework

\section{Hypothesis}

Based on the conceptual framework and previous research conducted by Darmawati (2016), Sirena and Bobby (2014), Henry (2013), Melysa (2013), Richie (2013), Dulkhatif, et al (2016), Septiadi and Hening (2013), Aberian and Ruzikna (2015), Galib (2013), Ren-Fang (2015), Listien, et al (2012), Novita (2012) and Rinny (2013), then the hypothesis can be determined as follows:

$\mathrm{H}_{1} \quad$ : Tangible has a significant positive effect on customer loyalty.

$\mathrm{H}_{2}$ : Reliability has a significant positive effect on customer loyalty.

$\mathrm{H}_{3}$ : Responsiveness has a significant positive effect on customer loyalty.

$\mathrm{H}_{4}$ : Assurance has a significant positive effect on customer loyalty.

$\mathrm{H}_{5}$ : Empathy has a significant positive effect on customer loyalty.

\section{Validity and Reliability Test Results}

The results of the validity and reliability tests can be seen in the following table 1:

Table 1. Validity and Reliability Item-Total Statistics

\begin{tabular}{|l|r|r|r|r|r|}
\hline & $\begin{array}{c}\text { Scale Mean if } \\
\text { Item Deleted }\end{array}$ & $\begin{array}{c}\text { Scale } \\
\text { Variance if } \\
\text { Item Deleted }\end{array}$ & $\begin{array}{c}\text { Corrected } \\
\text { Item-Total } \\
\text { Correlation }\end{array}$ & $\begin{array}{c}\text { Squared } \\
\text { Multiple } \\
\text { Correlation }\end{array}$ & $\begin{array}{c}\text { Cronbach's } \\
\text { Alpha if Item } \\
\text { Deleted }\end{array}$ \\
\hline x1 & 19,1883 & 15,465 &, 831 &, 704 &, 936 \\
x2 & 19,2283 & 15,444 &, 845 &, 726 &, 935 \\
x3 & 19,3250 & 15,774 &, 826 &, 692 &, 937 \\
x4 & 19,3058 & 15,880 &, 811 &, 674 &, 939 \\
x5 & 19,2158 & 15,812 &, 810 &, 680 &, 939 \\
y & 19,1783 & 15,416 &, 888 &, 790 &, 930 \\
\hline
\end{tabular}

In the table above, see the value of the Scale Corrected Item-Total Correlation, this value is the value of the validity of the items. While the Cronbach's Alpha if Item Deleted value is the item reliability value. 
Table 2. Reliability Test Results Table Reliability Statistics

\begin{tabular}{|c|c|c|}
\hline $\begin{array}{c}\text { Cronbach's } \\
\text { Alpha }\end{array}$ & $\begin{array}{l}\text { Cronbach's } \\
\text { Alpha Based } \\
\text { on } \\
\text { Standardized } \\
\text { Items }\end{array}$ & Nof ltems \\
\hline ,946 & 946 & 6 \\
\hline
\end{tabular}

In the reliability statistics table, see the value of Cronbach's Alpha Based on Standardized Items, this value is the overall reliability value of the test, the greater the value means the more reliable.

\section{Normality Test Results.}

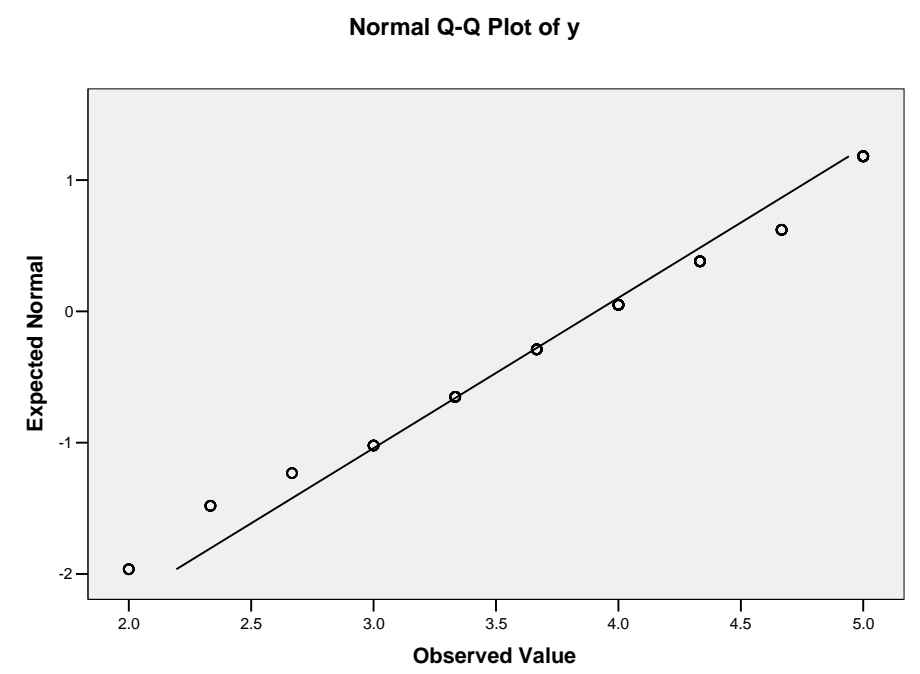

Figure 2. Normality Test Results

Based on the graph in the image above, it can be seen that the points on the graph coincide and follow the direction of the diagonal line, so it can be concluded that the data is normally distributed.

Table 3. Reliability Test Results Table

ANOVA

\begin{tabular}{|ll|r|r|r|r|r|}
\hline Model & & \multicolumn{1}{|c|}{$\begin{array}{c}\text { Sum of } \\
\text { Squares }\end{array}$} & df & Mean Square & F & Sig. \\
\hline 1 & Regression & 59,627 & 5 & 11,925 & 70,518 &, $000^{\mathrm{a}}$ \\
& Residual & 15,896 & 94 &, 169 & & \\
& Total & 75,523 & 99 & & & \\
\hline
\end{tabular}

a. Predictors: (Constant), x5, x4, x1, x3, x2

b. Dependent Variable: $y$ 
From the table above, the F-number simultaneously is 70.518 and the probability value is 0.000 smaller than the significance level of $5 \%$ or 0.05 ; So it can be concluded that there is a positive and significant influence between tangible, reliability, responsiveness, assurance, and empathy on customer loyalty, simultaneously (together) it means that the regression model is declared fit or feasible as a research model.

Table.4. Reliability Test Results Table

Coefficients $^{\mathrm{a}}$

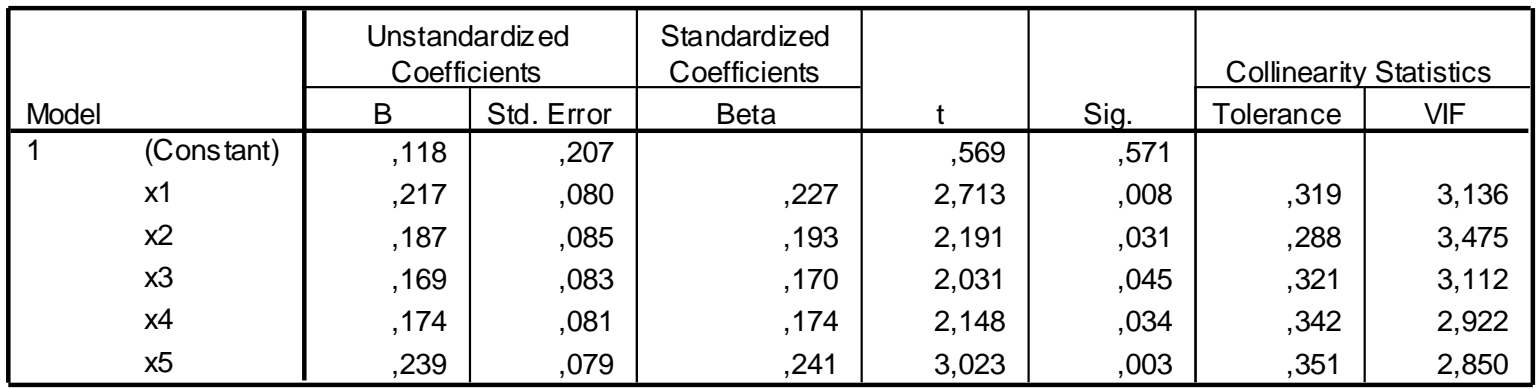

a. Dependent Variable: $y$

The results of the multiple linear regression equation above provide the understanding that :

a. The constant (b0) is 0.118 which means that if tangible, reliability, responsiveness, assurance and empathy remain or do not change, then customer loyalty will be positive.

b. The regression coefficient of tangible variables is 0.217 (positive), reliability is 0.187 (positive), responsiveness is 0.169 (positive), assurance is 0.174 (positive), empathy is 0.239 (positive), which means that the better consumer perceptions in responding to the indicators of the five variables this, it will be followed by an increase in customer loyalty.

Based on the results of the t-test, it can be proven as follows:

It can be seen that there is a positive influence between the tangible variable $\left(\mathrm{X}_{1}\right)$ on the customer loyalty variable (Y) with a t value of 2.713 and a significance or probability value of 0.008 < significance level of $5 \%$ or 0.05 . Then Ha is accepted thus stating that the tangible variable has a significant effect on customer loyalty. This indicates that the better the tangible has a good impact on increasing customer loyalty.

It can be seen that there is a positive influence between the variable reliability $\left(\mathrm{X}_{2}\right)$ on the customer loyalty variable (Y) with a t-value of 2.191 and a significance or probability value of $0.031<5 \%$ or 0.05 significance level. Then $\mathrm{Ha}$ is accepted, so that the variable reliability has a significant effect on customer loyalty. This indicates that better reliability has a good impact on increasing customer loyalty.

It can be seen that there is a positive influence between the responsiveness variable $\left(\mathrm{X}_{3}\right)$ on the customer loyalty variable (Y) with a t value of 2.031 and a significance or probability value of 0.045 <significance level of $5 \%$ or 0.05 . Then $\mathrm{Ha}$ is accepted, thus stating that the responsiveness variable has a significant effect on the customer. This indicates that the better responsiveness has a good impact on increasing customer loyalty.

It can be seen that there is a positive influence between the assurance variable $\left(\mathrm{X}_{4}\right)$ on the customer loyalty variable (Y) with a t value of 2.148 and a significance or probability value of 0.034 <significance level of $5 \%$ or 0.05 . So Ha is accepted so that the assurance variable has 
a significant effect on customer loyalty. This indicates that better the assurance has a good impact on increasing customer loyalty.

It can be seen that there is a positive influence between the empathy variable (X5) on the customer loyalty variable $(\mathrm{Y})$ with a t-value of 3.023 and a significance or probability value of $0.003<5 \%$ or 0.05 significance level. Then Ha is accepted, thus stating that the empathy variable has a significant effect on customer loyalty. This indicates that better empathy has a good impact on increasing customer loyalty.

Table 5. Determination Coefficient Results Model Summary

\begin{tabular}{|l|r|r|r|r|}
\hline Model & \multicolumn{1}{|c|}{$\mathrm{R}$} & $\mathrm{R}$ Square & $\begin{array}{c}\text { Adjusted } \\
\text { R Square }\end{array}$ & $\begin{array}{r}\text { Std. Error of } \\
\text { the Estimate }\end{array}$ \\
\hline 1 &, $889^{\mathrm{a}}$ &, 790 &, 778 &, 41123 \\
\hline
\end{tabular}

a. Predictors: (Constant), x5, x4, x1, x3, x2

Based on the results of regression calculations, the adjusted Coefficient of Determination (adjusted $\mathrm{R}^{2}$ ) is 0.778 , meaning that the variation of all independent variables (tangible, reliability, responsiveness, assurance, and empathy) can explain customer loyalty by $77.8 \%$. While the remaining $22.2 \%$ is explained by other variables not proposed in this study.

\section{CONCLUSION}

Based on the research results, the following conclusions can be drawn

The empathy variable becomes the first largest variable that affects customer loyalty of fast-food restaurants in the city of Semarang. The tangible variable is the second-largest variable affecting customer loyalty of fast-food restaurants in the city of Semarang. The variable reliability is the third largest variable affecting customer loyalty of fast-food restaurants in the city of Semarang. The assurance variable is the fourth largest variable affecting customer loyalty of fast-food restaurants in the city of Semarang. The responsiveness variable is the fifth largest variable that affecting customer loyalty of fast-food restaurants in the city of Semarang.The empathy variable is the highest variable affecting customer loyalty because, during the COVID 19 pandemic, personal service is needed. Each consumer is unique, so customer service needs vary. Customers can use delivery services, both take away, home delivery, drive-thru, online, and KFC box.Tangible variables, responsiveness, assurance, empathy partially have a positive and significant influence on customer loyalty.

\section{REFERENCES}

Chao, Ren-Fang, Tai-Chi Wu, and Wei-Ti Yen. (2015). The Influence Service Quality, Brand Image, and Customer Satisfaction on Customer Loyalty for Privat Karaoke Roomsin Taiwan. The Journal of Global Business Management. 11 (1), 59-67

Darmawati. (2016). The Effect of Service Quality on Customer Loyalty in Using Printing Services of CV Rahmat Nur in Samarinda. eJournal Ilmu Administrasi Bisnis. 4(1), 157171

Dulkhatif, Andi Tri Haryono, and Moh Mukeri Warso. (2016). The Influence of Service Quality, Customer Satisfaction and Location on Customer Loyalty to Internet Study Service Providers PT Noken Mulia Tama Semarang. Journal of Management. 2 (2) 
Ekasari, Novita. (2012). Effect of Service Delivery and Service Quality on Customer Loyalty at PT BFI Finance Jambi Branch. Jurnal Fakultas Ekonomi Universitas Jambi. 1(1), 5162

Herlistyani, Listien, Yunus Winoto, and Asep Saeful Rohman. (2012). Influence of Quality Information Services Telkom on Customer Loyalty Telkom Speedy to PT. Telekomunikasi Indonesia Tbk. eJurnal Mahasiswa Universitas Padjajaran. 1(1), 1-14

Kalalo, Rinny E. (2013). Customer Relationship Management and Service Quality Influence on Customer Loyalty of PT. Matahari Dept. Store, Manado. Jurnal EMBA. 1 (4), 15531561

Kotler, Philip, dan Lane Keller. (2009). Marketing Management. Jakarta: Erlangga.

--------, and Gary Armstrong. (2012). Marketing Principles. Jakarta: Erlangga.

Lovelock, Christopher, Jochen Wirtz, dan Jacky Mussry. (2010). Human Services Marketing, Technology, Strategy. Jakarta: Erlangga.

Piri, Henry G. (2013). Service Quality Affects Customer Loyalty at Steiner Salon Manado. Jurnal EMBA. 1 (4), 504-512

Pongoh, Melysa Elisabeth. (2013). Service Quality, Product Quality and Price Influence on US Telkomsel Customer Loyalty in Manado City. Jurnal EMBA. 1 (4), 86-94

Santoso, Septiadi, and Hening Widi Oetomo. (2013). The Influence of Service Quality on Customer Loyalty in Popular Clinical Laboratories in Surabaya. Jurnal Ilmu \& Riset Manajemen. 2 (6)

Tjiptono, F, and Chandra, G. (2012). Strategic Marketing. Yogyakarta: Andi.

Tjiptono, Fandy. (2013). Marketing Services. Malang : Bayumedia

Wangsanegara, Sirena Lucia, and Bobby Naedi Sopian. (2014). Effect of Online Reservation

Service Quality at PT. Kereta Api Indonesia to Passenger Loyalty. Jurnal Management Resort \& Leisure. 11 (1),25-33

Wungow, Richie. 2013. "Service Quality, Image, Value and Satisfaction Their Influence on Customer Loyalty at Rock Rand Hotel Manado". Jurnal EMBA. Vo.1 No.3, p: 90-98

https://ekonomi.bisnis.com

https://www.topbrand-award.com/top-brand-index/?tbi_find=kfc

https://jateng.idntimes.com/business/economy/anggun-puspitoningrum-1/cara-jitu-agar-

restoran-tetap-ramai-ditengah-merebaknya-virus-corona/1 